\title{
N-nitrosamine generation by urinary tract infections in spine injured patients
}

\author{
D J Stickler, D Phil, ${ }^{1} \mathrm{~J}$ C Chawla MD FRCS, ${ }^{2}$ A R Tricker PhD,${ }^{3}$ R Preussmann Prof \\ Dr rer nat ${ }^{3}$ \\ ${ }^{1}$ School of Pure and Applied Biology, University of Wales, College of Cardiff, Cardiff \\ CF1 3TL, Wales, UK; ${ }^{2}$ Spinal Injuries Unit, Rookwood Hospital, Cardiff CF5 2YN, \\ Wales UK; ${ }^{3}$ Department of Enviromental Carcinogenesis, Institute of Toxicology and \\ Chemotherapy, German Cancer Research Centre, $1 m$ Neuenheimer Feld 280, \\ D6900-Heidelberg, Germany.
}

Urine was collected from 33 patients resident at the Welsh Spinal Injuries Unit and analysed for volatile $\mathrm{N}$-nitrosamines by gas chromatography. N-nitrosodimethylamine, $\mathrm{N}$-nitrosopiperidine or $\mathrm{N}$-nitrosopyrrolidine was detected in 32 of the samples. Thirty-one of the samples were infected by one or more microbial species. Nitrate and $\mathrm{N}$-nitrosamines were not found in the sterile urines of a group of 10 control individuals exposed to the same dietary and enviromental influences as the spinal patients. Although N-nitrosamines were found in some of the catheter drainage system products, they did not elute into urine on 24-h exposure. In addition, 6 of the nitrosamine-containing urines had no contact with drainage systems as they were collected from spinal patients who were capable of independent voiding. It was concluded that the nitrosamines detected in the urines arose from the bacterial nitrosation of urinary amines. These results support the hypothesis that chronic urinary tract infection may have a role in the aetiology of bladder cancer in spine injured patients.

Keywords: N-nitrosamines; bladder cancer; urinary tract infections; spinal cord injury.

\section{Introduction}

In 1956 Magee and Barnes ${ }^{1}$ demonstrated that dimethylnitrosamine could induce primary malignant hepatic tumours in the rat. Since then it has been recognised that many chemical analogues containing the $\mathrm{N}-\mathrm{NO}$ nitroso group attached to a variety of alkyl and other organic groupings (Fig 1) are carcinogenic, producing tumours in many different organs in various species of experimental animals. Humans are exposed to these carcinogens from food, the environment, ${ }^{2}$ and from the nitrosation of amine precursors in the body. ${ }^{3}$ On the basis of epidemiological evidence it has been proposed that $\mathrm{N}$-nitrosamines may have roles in the aetiology of human cancer of the stomach, oesphagus, nasopharyx, and bladder. ${ }^{4.5}$

In the case of carcinoma of the bladder, much of the incriminating evidence comes from a study of the extremely high rates of bladder cancer among young men in rural Egypt. For many years it has been recognised that there is an association between the incidence of bladder cancer and schistosomiasis (bilharziasis) in agricultural workers in the Nile valley, and a comparative<smiles>CN(C)[N+](=O)[O-]</smiles>

$\mathrm{N}$-nitrosodimethylamine<smiles>ON1CCCCC1</smiles>

$\mathrm{N}$-nitrosopiperidine<smiles>CCN(CC)N=O</smiles>

N-Nitrosodiethylamine<smiles>O=NN1CCCC1</smiles>

$\mathrm{N}$-nitrosopyrrolidine
Figure 1 Some carcinogenic N-nitrosamines. 
case-control study demonstrated a strong relationship between the incidence of bladder cancer and endemic bilharzia. ${ }^{6}$

The cercaria of the schistosome worms present in the waters of Nile infect man by penetrating the skin on any part of the body submerged in the infected water. The worms mate in the ducts of the human liver and migrate to the walls of the bladder and the intestine, where the female lays thousands of eggs, which eventually pass out with the urine and faeces. It has been postulated that the chronic urinary tract bacterial infections that become associated with the infestation and inflammation of the bladder wall predisposes the Schistosoma haematobium - infected bilharzial patient to bladder cancer. ${ }^{7}$

Hill and Hawksworth ${ }^{8}$ suggested that, as normal urine will always contain nitrates and secondary amines from dietary and endogenous sources, infection of the urinary tract with nitrate-reducing bacteria sets up conditions under which production of $\mathrm{N}$ nitrosamines might occur in the bladder. Hicks et $a l^{7}$ examined this hypothesis in a study of the nitrosamine content of urine from 2 groups of patients subject to chronic urinary tract infection. Single samples of urine were taken from 5 Egyptian agricultural workers hospitalised for treatment of neoplastic bladder disease superimposed on bilharzia of the urinary bladder. Three of these were shown to contain nitrosamines.

The second group consisted of 11 men with spinal injuries, all having histories of recurrent bacteriuria. Significant amounts of nitrosamines were detected in urine samples from 3 of these patients. There is evidence that this group of patients is also predisposed to carcinoma of the bladder. ${ }^{9}$

Tricker et al ${ }^{10}$ re-examined the urinary generation of $\mathrm{N}$-nitroso compounds in patients with bilharzia. They confirmed that significant formation of nitrite and nitrosamines occurs in the bladders of these patients. They also noted that the urinary tract in these Schistosoma-infected Egyptian patients becomes infected by complex microbial populations including a range of faecal bacteria. In vitro studies ${ }^{11-13}$ have confirmed that organisms commonly found in these chronic infections, such as Escherichia coli, Proteus morganii, Pseudomonas aeruginosa, Enterobacter aerogenes and Klebsiella pneumoniae, have the ability to reduce nitrate and use the nitrite formed to nitrosate secondary amines. As these same bacterial species commonly and persistently colonise the urinary tracts of paraplegic patients, ${ }^{14}$ it is to be expected that this group will also suffer long term exposure to nitrosamines formed endogenously in the bladder. As the preliminary work of Hicks et $a l^{7}$ appears to be the only information in the literature on the endogenous generation of $\mathrm{N}$-nitrosamines in this high risk population for bladder cancer, we have determined the concentrations of nitrate, nitrite, nitrosatable amines and volatile $\mathrm{N}$-nitroso compounds in the urine of 33 paraplegic patients.

\section{Methods}

\section{Subjects}

Patients in the Welsh Spinal Unit at Rookwood Hospital, Cardiff, provided urine samples for this study. Of the 33 patients, 13 had indwelling catheters, 5 were undergoing intermittent catheterisation, 7 had external condom drainage, one had a suprapubic catheter, one had a conduit bag and 6 were capable of controlled micturition without the aid of a bladder drainage system. A control group of 10 uninfected individuals was made up of staff and patients from other units in the same hospital.

\section{Collection and storage of urine samples}

Urine (24-h samples) for chemical analysis was collected from all patients and controls with alkaline stabilisation used to prevent artefact $\mathrm{N}$-nitrosamine formation and bacterial growth. Urine samples from patients with indwelling catheters or external condom drainage were removed frequently from the drainage reservoirs and made alkaline; urine from control and patients undergoing intermittent catheterisation was collected directly into polyethylene bottles containing $\mathrm{NaOH}$.

Total daily urine volumes were recorded 
and aliquots $(50-60 \mathrm{ml})$ frozen at $-20^{\circ} \mathrm{C}$ and flown to Heidelberg for chemical analysis.

Urine was also collected for bacteriological analysis. In patients with indwelling catheters, samples were aspirated from the catheter. With patients managed by intermittent catheterisation, subsamples were collected directly from the catheter outlet. For those with condom drainage, the condom was removed, the urethral meatus cleaned with water and a mid stream urine sample obtained by bladder expression. Mid stream samples were also obtained from control individuals. After collection all samples were transported to the laboratory for immediate analysis.

\section{Chemical analysis}

Nitrate, nitrite and volatile $\mathrm{N}$-nitrosamines in urine were determined by the methods previously reported by Tricker et al ${ }^{10}$ The $\mathrm{N}$-nitrosamine content of catheters, drainage tubing and bags, condoms and catheter lubrication jelly was determined by the method of Havery and Fazio. ${ }^{15}$ Amine analysis was performed by a modification of the method of Pfundstein et al ${ }^{16}$ using gas chromatography and chemiluminescence detection with a modified thermal energy analyser. Aliquots $(20 \mathrm{ml})$ of urine were incubated at $105^{\circ} \mathrm{C}$ for $60 \mathrm{~min}$ in a sealed glass reaction vial containing $10 \mathrm{M} \mathrm{NaOH}$ $(1 \mathrm{ml})$, ethylpropylamine (internal standard $10 \mathrm{mg}$ ) and benzenesulphonylchloride $(0.3 \mathrm{ml})$. The benzenesulphonamides of secondary amines were isolated using a modified Hinsberg separation by extraction with hexane, washed by back extraction with $1 \mathrm{M} \mathrm{NaOH}$ and concentrated under a stream of nitrogen for analysis by gas chromatography.

\section{Microbiological analysis}

Urine was cultured on CLED Agar (Oxoid Ltd) overnight at $37^{\circ} \mathrm{C}$. Viable bacterial cell counts were performed by the method of Miles and Misra ${ }^{17}$ and bacteria identified by the methods of Cowan and Steele ${ }^{18}$ and with the appropriate microtube system (API Ltd).

\section{Results}

The results of bacteriological examination of paraplegic patients' urine samples together with the results of analysis for urinary nitrate, nitrite, nitrosatable secondary amines and volatile $\mathrm{N}$-nitrosamines are presented in Tables I-III. It can be seen that only 2 of the 33 urines were sterile; 11 of the urines were infected with single species and 20 with mixed populations of organisms. With those patients infected with single organisms (Table I) it is clear that nitrate reduction was taking place in the urine and that pure cultures of at least 5 microbial species were capable of $\mathrm{N}$-nitrosamine synthesis. The mixed communities of microbes also displayed nitrosating capacity (Table II).

Nitrosamines were detected in the urines of all 6 patients who were capable of controlled voiding and whose urine had no contact with catheters or drainage tubing. In contrast, sterile urine from control volunteers from the same hospital enviroment as the paraplegics contained no detectable free nitrite or volatile $\mathrm{N}$-nitroso compounds, despite the presence of the precursor nitrate and nitrosatable amines (Table IV).

The results from the analysis of the catheters, condoms, drainage tubing or bags for volatile $\mathrm{N}$-nitrosamines are presented in Table V. The highest nitrosamine levels were found in latex condoms. To check that artefact contamination of urine by the elution of volatile $\mathrm{N}$-nitrosamines did not occur from rubber contact materials, a sterile urine sample was analysed prior to and after standing for $24 \mathrm{~h}$ in contact with a condom, a duplicate sample from the same production batch as condom No 5, (Table V). No volatile $\mathrm{N}$-nitrosamines were detected in either the before or after samples, and no significant increase in the levels of secondary amines was detected after $24 \mathrm{~h}$.

\section{Discussion}

As expected, most (31 of 33) of the urine samples from the paraplegic patients were infected by one or more microbial species. The nitrosating capacity of the urinary flora was evident from the significant levels of volatile nitrosamines in 32 of 33 samples. It 
Table I Nitrate, nitrite, secondary amines and N-nitrosamines in urine of patients undergoing bladder drainage and infected with single microbial species

\begin{tabular}{|c|c|c|c|c|c|c|c|c|}
\hline \multirow[t]{2}{*}{ Patient } & \multirow[t]{2}{*}{ Bacteria isolated } & \multirow[t]{2}{*}{$\begin{array}{c}\mathrm{NO}_{3}^{-} \\
(\mathrm{mg} / \text { day })\end{array}$} & \multirow[t]{2}{*}{$\begin{array}{c}\mathrm{NO}_{2}^{-} \\
(\mathrm{mg} / \text { day })\end{array}$} & \multirow[t]{2}{*}{$\begin{array}{c}\text { Secondary amines }{ }^{+} \\
(\mathrm{mg} / \text { day })\end{array}$} & \multicolumn{4}{|c|}{$\begin{array}{l}\text { Volatile N-nitrosamines } \\
\qquad(\mu \mathrm{g} / \text { day })\end{array}$} \\
\hline & & & & & NDMA & NDEA & NPIP & NPYR \\
\hline $1 a^{*}$ & Candida albicans & 62.0 & 2.70 & 134.12 & 2.68 & ND & ND & ND \\
\hline $2 a$ & Klebsiella oxytoca & 80.3 & 15.70 & 39.17 & 0.48 & ND & ND & ND \\
\hline $3 a$ & Escherichia coli & 16.3 & 28.10 & 66.48 & 0.12 & ND & 0.23 & 0.23 \\
\hline $4 \mathrm{~b}$ & Escherichia coli & 13.8 & 18.00 & 44.74 & 0.14 & ND & ND & ND \\
\hline $5 a$ & Providencia stuartii & 24.3 & 49.90 & 81.03 & 0.13 & ND & 0.38 & 0.19 \\
\hline $6 b$ & Proteus mirabilis & 61.3 & 7.30 & 85.81 & 0.59 & ND & 0.30 & 1.26 \\
\hline $7 a$ & Diphtheroids & 99.2 & ND & 86.35 & 0.05 & ND & ND & ND \\
\hline $8 \mathrm{c}$ & Proteus mirabilis & 124.8 & ND & 171.88 & 1.00 & ND & 0.60 & 0.40 \\
\hline $9 c$ & Providencia stuartii & 25.1 & 1.80 & 116.10 & 0.60 & ND & ND & 1.20 \\
\hline $10 \mathrm{c}$ & Escherichia coli & 8.7 & 1.49 & 124.26 & 0.25 & 0.50 & ND & 1.25 \\
\hline $11 d$ & Escherichia coli & 33.4 & 9.15 & 73.24 & 0.45 & ND & 0.18 & 0.27 \\
\hline $12 \mathrm{a}$ & Sterile & 28.4 & 0.30 & 58.33 & 0.08 & ND & ND & 0.15 \\
\hline $13 c$ & Sterile & 47.3 & ND & 158.94 & 0.41 & ND & ND & ND \\
\hline
\end{tabular}

* Method of bladder drainage: $a=$ indwelling catheter, $b=$ condom, $c=$ intermittent catheterisation, $d=$ conduit bag.

+ The amines detected included dimethylamine (DMA), diethylamine (DEA), piperidine (PIP) and pyrrolidine (PYR).

NDMA $=\mathrm{N}$-nitrosodimethylamine, NDEA $=\mathrm{N}$-nitrosodiethylamine; NPIP $=\mathrm{N}$-nitrosopiperidine $; \mathrm{NPYR}=\mathrm{N}$-nitrosopyrrolidine $;$ ND $=$ not detected. 
Table II Nitrate, nitrite, secondary amines and $\mathrm{N}$-nitrosamines in urine of patients undergoing bladder drainage and infected with mixed microbial populations

\begin{tabular}{|c|c|c|c|c|c|c|c|}
\hline \multirow[t]{2}{*}{ Patient } & \multirow[t]{2}{*}{$\begin{array}{c}\mathrm{NO}_{3}^{-} \\
(\mathrm{mg} / \text { day })\end{array}$} & \multirow[t]{2}{*}{$\begin{array}{l}\mathrm{NO}_{2}^{-} \\
(\mathrm{mg} / \text { day })\end{array}$} & \multirow[t]{2}{*}{$\begin{array}{l}\text { Secondary amines }{ }^{+} \\
\text {(mg/day) }\end{array}$} & \multicolumn{4}{|c|}{$\begin{array}{c}\text { Volatile N-nitrosamines } \\
\qquad(\mu \mathrm{g} / \text { day })\end{array}$} \\
\hline & & & & NDMA & NDEA & NPIP & NPYR \\
\hline $14 \mathrm{a}^{*}$ & 1.6 & 6.40 & 75.13 & 0.14 & ND & 0.48 & 0.34 \\
\hline $15 a$ & 34.6 & 15.70 & 103.79 & 0.40 & ND & 2.13 & 1.20 \\
\hline $16 a$ & 53.4 & 4.20 & 71.03 & 0.30 & ND & ND & ND \\
\hline $17 \mathrm{a}$ & 15.6 & 9.00 & 89.08 & 0.30 & ND & 0.30 & 0.60 \\
\hline $18 \mathrm{a}$ & 13.8 & 43.10 & 108.09 & 0.73 & ND & ND & 0.36 \\
\hline $19 a$ & 47.2 & ND & 55.74 & 0.29 & ND & ND & ND \\
\hline $20 \mathrm{a}$ & 30.3 & 11.90 & 107.19 & 0.30 & ND & 0.20 & 0.30 \\
\hline $21 b$ & 27.0 & 1.20 & 132.78 & 0.90 & ND & 0.60 & 0.60 \\
\hline $22 b$ & 47.2 & 13.30 & 34.17 & 0.35 & ND & 0.05 & 0.10 \\
\hline $23 b$ & 48.6 & 8.40 & 159.77 & 0.35 & ND & ND & ND \\
\hline $24 c$ & 81.1 & 11.80 & 99.77 & 0.36 & 2.16 & 0.36 & 0.72 \\
\hline $25 c$ & 53.6 & ND & 55.38 & 15.68 & ND & ND & ND \\
\hline $26 c$ & 35.1 & 0.72 & 83.60 & 0.09 & ND & ND & 0.27 \\
\hline $27 \mathrm{~d}$ & 47.7 & 42.10 & 63.52 & 0.43 & ND & ND & ND \\
\hline
\end{tabular}

${ }^{*}$ Method of bladder drainage: $\mathrm{a}=$ indwelling catheter, $\mathrm{b}=$ condom, $\mathrm{c}=$ intermittent catheterisation, $\mathrm{d}=$ suprapubic aspiration.

+ The amines detected included DMA, DEA, PIP and PYR.

Abbreviations as in Table I.

is interesting that nitrosamines were detected in the 2 sterile samples. A possible explanation for this observation is that these patients, who were undergoing bladder management by indwelling catheter and by condom drainage, had sterile urines because they were being treated with antibiotics at the time of sampling. It is known that under these conditions, while antibiotics eliminate planktonic bacteria from the urine, cells colonising the surfaces of the catheters remain viable. ${ }^{19}$ It might be that these biofilms of organisms on catheter surfaces are capable of generating urinary nitrosamines.

Urines from the control group of individuals, who were exposed to the same dietary and enviromental influences as the spine injured patients, were all sterile. While nitrate and nitrosatable amines were present in all these urines, nitrite and nitrosamines were not found (Table IV).

Examination of Table I indicated that at least 5 different microbial species were capable of nitrosation. With the exception of Providencia stuartii, which is a particularly common coloniser of the catheterised urinary tract, ${ }^{20}$ all these organisms have been shown to be capable of reducing nitrate to nitrite and nitrosating amines. ${ }^{11-13,21}$

$\mathrm{N}$-nitrosamine contamination of rubber products $^{22}$ and urinary catheters ${ }^{23}$ is well documented. The results presented in Table III, however, show that the carcinogens were present in infected urine from patients capable of independent voiding, urine that had not been in contact with any of the suspect materials; together with the observations that although condoms contained $\mathrm{N}$-nitrosodimethylamine (NDMA; Table V) $\mathrm{N}$-nitrosamines did not elute from them on storage for $24 \mathrm{~h}$ in human urine, these results eliminate the possibility that the reported $\mathrm{N}$-nitrosamine levels in the urine of spine injured patients resulted from migratory contamination of these compounds from the catheters, condoms, drainage tubing and bags, or other contact materials. It would thus appear that the data reported in Tables I-III are free from artifact contamination.

Melzak $^{24}$ recorded 12 cases of urothelial cancer compared to only 5 cases of lung 
Table III Nitrate, nitrite, secondary amines and N-nitrosamines in urine of patients capable of independent voiding

\begin{tabular}{|c|c|c|c|c|c|c|c|c|}
\hline \multirow[t]{2}{*}{ Patient } & \multirow[t]{2}{*}{ Organism isolated } & \multirow[t]{2}{*}{$\begin{array}{c}\mathrm{NO}_{3}^{-} \\
\text {(mg/day) }\end{array}$} & \multirow[t]{2}{*}{$\begin{array}{c}\mathrm{NO}_{2}^{-} \\
\text {(mg/day) }\end{array}$} & \multirow[t]{2}{*}{$\begin{array}{c}\text { Secondary amines }{ }^{+} \\
(\mathrm{mg} / \text { day })\end{array}$} & \multicolumn{4}{|c|}{$\begin{array}{c}\text { Volatile N-nitrosamines } \\
\qquad(\mu \mathrm{g} / \text { day })\end{array}$} \\
\hline & & & & & NDMA & NDEA & NPIP & NPYR \\
\hline 28 & Proteus mirabilis & 146.5 & ND & 97.85 & 0.25 & ND & ND & 0.25 \\
\hline 29 & $\begin{array}{l}\text { Streptococcus faecalis } \\
\text { Diphtheroids }\end{array}$ & 54.1 & 12.1 & 167.33 & 2.50 & ND & 0.74 & 0.92 \\
\hline 30 & Klebsiella pneumoniae & 15.1 & 0.9 & 116.10 & 1.02 & ND & 0.19 & 0.44 \\
\hline 31 & Escherichia coli & 5.0 & ND & 45.89 & 0.64 & ND & 0.46 & 0.74 \\
\hline 32 & Escherichia coli & 46.6 & 19.8 & 48.43 & 0.99 & ND & 0.13 & 0.46 \\
\hline 33 & Escherichia coli & 16.7 & 5.8 & 54.94 & 0.38 & ND & ND & 0.10 \\
\hline
\end{tabular}

+ The amines detected included DMA, DEA, PIP and PYR.

Abbreviations as in Table I. 
Table IV Nitrate, nitrite, secondary amines and $\mathrm{N}$-nitrosamines in sterile urines from control subjects

\begin{tabular}{|c|c|c|c|c|c|c|c|c|c|c|}
\hline \multirow[t]{2}{*}{ Subject } & \multirow[t]{2}{*}{$\begin{array}{c}\mathrm{NO}_{3}^{-} \\
(\mathrm{mg} / \text { day })\end{array}$} & \multirow[t]{2}{*}{$\begin{array}{l}\mathrm{NO}_{2}^{-} \\
(\mathrm{mg} / \text { day })\end{array}$} & \multicolumn{4}{|c|}{$\begin{array}{l}\text { Secondary amines } \\
\text { (mg/day) }\end{array}$} & \multicolumn{4}{|c|}{$\begin{array}{c}\text { Volatile N-nitrosamines } \\
(\mu \mathrm{g} / \text { day })\end{array}$} \\
\hline & & & DMA & DEA & PIP & PYR & NDMA & NDEA & NPIP & NPYR \\
\hline 1 & 98.7 & ND & 33.70 & ND & 7.31 & 12.49 & ND & ND & ND & ND \\
\hline 2 & 151.9 & ND & 36.00 & ND & 11.17 & 25.68 & ND & ND & ND & ND \\
\hline 3 & 104.7 & ND & 46.07 & 0.62 & 101.13 & 31.30 & ND & ND & ND & ND \\
\hline 4 & 40.7 & ND & 31.36 & ND & 7.01 & 4.57 & ND & ND & ND & ND \\
\hline 5 & 29.7 & ND & 28.61 & ND & 6.42 & 7.61 & ND & ND & ND & ND \\
\hline 6 & 101.8 & ND & 40.64 & ND & 14.68 & 17.93 & ND & ND & ND & ND \\
\hline 7 & 105.4 & ND & 45.01 & ND & 23.70 & 41.01 & ND & ND & ND & ND \\
\hline 8 & 117.3 & ND & 55.77 & ND & 32.47 & 45.01 & ND & ND & ND & ND \\
\hline 9 & 85.0 & ND & 93.44 & ND & 53.22 & 24.72 & ND & ND & ND & ND \\
\hline 10 & 54.0 & ND & 41.52 & ND & 10.67 & 10.62 & ND & ND & ND & ND \\
\hline
\end{tabular}

Abbreviations as in Table I.

Table V N-Nitrosamine contamination of urological catheters, condoms and drainage bags

\begin{tabular}{lcccccc}
\hline Continence device & \multicolumn{5}{c}{ Volatile N-nitrosamines $(\mu \mathrm{g} / \mathrm{kg})^{*}$} \\
\cline { 2 - 6 } & NDMA & NDEA & NDPA & NDBA & NPIP & NMOR \\
\hline 1 Penis condom & ND $^{+}$ & ND & ND & 104.0 & 2.0 & ND \\
2 Penis condom & 0.3 & 2.6 & ND & 18.5 & 1.3 & ND \\
3 Penis condom & 0.6 & ND & ND & 14.8 & 1.8 & ND \\
4 Penis condom & 1.8 & ND & ND & 16.5 & 2.1 & ND \\
5 Penis condom & 2.6 & ND & ND & 4.4 & 94.0 & ND \\
6 Penis condom & 0.2 & ND & ND & 25.6 & ND & ND \\
7 Lubricating jelly & ND & ND & ND & ND & ND & ND \\
8 Catheter (silicon) & ND & ND & ND & 20.0 & ND & 12.0 \\
9 Catheter (silicon) & 1.2 & ND & 1.6 & 12.0 & 10.0 & ND \\
10 Catheter (silicon) & ND & ND & 12.0 & 10.0 & ND & ND \\
11 Catheter (Netalon) & ND & ND & ND & ND & ND & ND \\
12 Drainage bag & ND & ND & ND & ND & ND & ND \\
13 Drainage bag & ND & ND & ND & ND & ND & ND \\
14 Drainage bag & ND & ND & ND & ND & ND & ND \\
\hline
\end{tabular}

*Volatile nitrosamines: $\quad$ NDMA $=\mathrm{N}$-nitrosodiethylamine; $\quad$ NDPA $=\mathrm{N}$-nitrosodipropylamine; NDBA $=\mathrm{N}$-nitrosobutylamine; DPIP $=\mathrm{N}$-nitrosopiperidine; NMOR $=\mathrm{N}$-nitrosomorpholine

${ }^{+} \mathrm{ND}=$ not detected. Limits of detection: $0.1 \mu \mathrm{g} / \mathrm{kg}$ rubber.

cancer in 3800 spine injured patients at the National Spinal Injury Centre at Stoke Mandeville Hospital between 1944 and 1966. He also noted that the only common factor in the 12 cases was long-standing chronic bladder infections. An examination of the death certificates of men and women dying of bladder cancer in England and Wales between 1949 and 1974 led Davies ${ }^{9}$ to the conclusion that there was an excessive mortality from bladder cancer among paraplegics and other patients likely to suffer chronic urinary infection. Kaufman et al ${ }^{25}$ performed random bladder and urethral biopsies on 62 spinal injured patients and found that 6 had diffuse squamous cell bladder carcinoma.

A review of the histological records of 
6744 paraplegic and tetraplegic patients at Stoke Mandeville Hospital revealed 25 cases of bladder carcinoma. ${ }^{26}$ Twenty-one of these patients had died of their bladder tumours. The expected number of deaths in this group calculated from national statistics was 1.1. El-Masri and Fellows ${ }^{26}$ concluded that cord injury increased the risk of dying of bladder cancer by a factor of about 20 .

Locke et $a^{27}$ conducted bladder biopsies on a group of 25 spine injured patients who had been undergoing bladder catheterisation for a minimum of 10 years. Two cases of squamous cell carcinoma of the bladder were identified and both patients died within 5 months of diagnosis. All patients also showed squamous metaplasias, potentially premalignant lesions. As squamous cell carcinoma is an aggressive rapidly growing and infiltrative tumour with an unfavourable prognosis, Locke et al ${ }^{27}$ recommended the close monitoring of all patients with long term indwelling bladder catheters for early evidence of cancer.

The endogenous generation of nitrosamines by urinary tract infections in these patients could provide an explanation of this increased incidence of bladder carcinoma. It must be emphasised, however, that N-nitrosamines are not themselves directly carcinogenic; they have to be metabolised to the corresponding alkyldiazonium ions, which are the biologically active moieties capable of alkylating DNA and inducing cell damage, mutagenesis and carcinogenesis. ${ }^{28}$ Furthermore, urothelial bladder cells activate $\mathrm{N}$-nitrosamines (including NDMA) by hydroxylation to produce alkylating species. ${ }^{29-31}$ While there is epidemiological evidence that bacterial infections of the urinary tract may be a risk factor for cancer of the bladder, ${ }^{32.33}$ it is not known whether this nitrosamine-induced formation of DNA adducts takes place in the chronically infected human bladder.

Spine injured patients are a particularly appropriate group in which to examine this issue. Many of these patients are young men with previously healthy urinary tracts. Following spinal injury they will undergo chronic bladder colonisation by nitrosamine-generating bacterial communities. It is common practice, because of the pressures to limit the use of antibiotics, to withhold treatment of these infected bladders until patients present clinical symptoms of pyelonephritis or septicaemia. ${ }^{34.35}$ The bladder epithelia of these patients are thus exposed to long term contact with these carcinogens. If DNA adducts are produced in bladder epithelial cells under these circumstances it will not only substantiate the aetiological role of urinary tract infection in bladder cancer but will also strengthen the case for more aggresive antibiotic treatment of these infections.

\section{References}

1 Magee PN, Barnes JM (1956) The production of malignant primary hepatic tumours in the rat by feeding dimethylnitrosamine. Br J Cancer 10: 114-122.

2 Preussmann R, Eisenbrand G (1984) N-nitroso carcinogens in the enviroment. In: Searle CE, editor. Chemical Carcinogens, ACS Monograph No. 182. American Chemical Society, Washington DC: 829-868.

3 Ohshima H, Calmels S, Pignatelli B, Vincent P, Bartsch H. (1987) N-nitrosamine formation in urinary tract infections In: Bartsch H, O`Neill I, Schulte-Hermann R, editor. Relevance of N-nitroso Compounds to Human Cancer: Exposure and Mechanisms. IARC Scientific Publications No. 84. IARC, Lyon: 384-390.

4 Magee PN (1989) The experimental basis for the role of nitrosamines in human cancer. Cancer Surveys 8: 207-239.

5 Preston-Martin S, Correa P. (1989) Epidemiological evidence for the role of nitroso compounds in human cancer. Cancer Surveys 8: 459-473.

6 Ibahim AS, Elsebai I (1983) Epidemiology of bladder cancer. In: Elsebai I editor. Bladder Cancer. Vol. 1. CRC Press, Boca Raton, Florida: 17-37.

7 Hicks RM, Walters CL, Elsebai I, El-Aasser AB, El-Merzabini M, Gough TA (1977) Demonstration of nitrosamines in human urine. Proc $R$ Soc Med 70: 413-416.

8 Hill MJ, Hawksworth G (1972) Bacterial production of nitrosamines in vitro and in vivo. In: Bogouski P, Preussmann R, Walker EA, editors. N-nitroso Compounds, Analysis and Formation. IARC Scientific Publication No. 3. IARC, Lyon: 116-121.

9 Davies JM (1977) Two aspects of the epidemiology of bladder cancer in England and Wales. Proc $R$ Soc Med 70: 411-413. 
10 Tricker AR, Mostafa MH, Speigelhalder B, Preussmann R (1989) Urinary excretion of nitrate, nitrite and $\mathrm{N}$-nitroso compounds in schistosomiasis and bilharzial bladder cancer patients. Carcinogensis 10: 547-552.

11 Leach S, Challis B, Cook A, Hill M, Thompson M (1985) Bacterial catalysis of the N-nitrosation of secondary amines. Biochem Soc Trans 13: 380-381.

12 Calmels S, Ohshima H, Bartsch H (1988) Nitrosamine formation by denitrifying and non-denitrifying bacteria: implication of nitrite and nitrate reductase in nitrosamine catalysis. J Gen Microbiol 134: 221-226.

13 O`Donnell CM, Edwards C, Ware J (1988) Nitrosamine formation by clinical isolates of enteric bacteria. FEMS Microbiol Letters 51: 193-198.

14 Clayton CL, Chawla JC, Stickler DJ (1982) Some observations on urinary tract infections in patients undergoing long-term bladder catheterization. J Hosp Infect 3: 39-47.

15 Havery DC, Favery T (1982) Estimation of volatile N-nitrosamines in rubber nipples for babies bottles. Food Chem Toxic 20: 939-944.

16 Pfundstein B, Tricker AR, Preussmann R (1991) Analysis of primary and secondary amines in foodstuffs using gas chromatography and chemiluminescence detection with a modified Thermal Energy Analyser. $J$ Chromatogr 539: 141-148.

17 Miles AA, Misra SS (1938) The estimation of the bactericidal power of blood. J Hygiene 38: 732-748.

18 Cowan ST, Steel KJ (1974) Manual for the Identification of Medical Bacteria. 2nd ed. Cambridge University Press, Cambridge.

19 Nickel JC, Ruseska I, Wright JB, Costerton JW (1985) Tobramycin resistance of Pseudomonas aeruginosa cells growing as a biofilm on urinary catheter material. Antimicrobial Agent and Chemother 27: 619-625.

20 Stickler DJ (1976) Sensitivity of Providence to antiseptics and disinfectants. J Clin Path 29: 815-823.

21 Krogh P, Hald B, Holmstrup P (1987) Possible mycological etiology of oral mucosal cancer: catalytic potential of infecting Candida albicans and other yeasts in the production of $\mathrm{N}$-nitrosobenzylmethylamine. Carcinogenesis 8: 1543-1548.

22 Speigelhalder B, Preussmann R (1982) N-nitrosamines in rubber. In: Bartsch H, O`Neill IK, Castegnaro M, Okada M, editors. N-Nitrosocompounds: Occurrence and Biological Effects. IARC Scientific Publication No. 41. IARC, Lyon: 231-243.

23 Heenan MP, Nacey JN, Delahunt B, Ferguson AF, Dickson SJ (1989) Volatile N-nitrosamines in urinary catheters. Br J Urol 63: 72-75.

24 Melzak J (1966) The incidence of bladder cancer in paraplegia. Paraplegia 4: 85-96.

25 Kaufman JM, Fam B, Jacobs SC, Gabilando F, Yalla S, Kane JP, et al (1977) Bladder cancer and squamous metaplasia in spinal metaplasia in spinal cord injury patients. J Urol 118: 967-971.

26 El-Masri WS, Fellows G (1981) Bladder cancer after spinal cord injury. Paraplegia 19: 265-270.

27 Locke JR, Hill DE, Walzer Y (1985) Incidence of squamous cell carcinoma in patients with long term catheter drainage. J Urol 133: 1034-1035.

28 Saffhill R, Margison GP, O`Connor PJ (1985) Mechanisms of carcinogenesis induced by alkylating agents. Biochim Biophys Acta 823: 111-145.

29 Autrup H, Grafstrom RC, Christenșen B, Kieler J (1981) Metabolism of chemical carcinogens by cultured human and rat bladder epithelial cells. Carcinogenesis 2: 763-768.

30 Moore CM, Goodall CM, Beagley KW, Stephens OB, Horne L, Noronha RFX (1985) Mutagenic activation of dialkylnitrosamines by intact urothelial cells. Mutat Res 157: 95-105.

31 Ariolodi L, Magagnotti C, Bonfanti M, Fanelli R (1990) Alpha-oxidative metabolism of the bladder carcinogens $\mathrm{N}$-nitrosobutyl (4-hydroxybutyl)amine and $\mathrm{N}$-nitrosobutyl (3-carboxypropyl)amine within the rat isolated bladder. Carcinogenesis 11: 1437-1440.

32 Wynder EL, Onderdonk J, Mantel N (1963) An epidemiological investigation of cancer of the bladder. Cancer 16: 1388-1407.

33 Kantor AF, Hartge P, Hoover RN, Narayana AS, Sullivan JW, Fraumeni JF (1984) Urinary tract infections and risk of bladder cancer. Am J Epidemiol 119: 510-515.

34 Galloway A, Green HT, Windsor JJ, Menon KK, Gardner BD (1986) Serial concentrations of C-reactive protein as an indicator of urinary tract infection in patients with spinal injury. J Clin Path 39: 851-855.

35 Stickler DJ, Chawla JC (1988) An appraisal of antibiotic policies for urinary tract infections in patients with spinai cord injuries undergoing long term intermittent catheterization. Paraplegia 26: 215-225. 